\title{
Penerapan Model Pembelajaran Student Teams Achievement Division (STAD) dalam Meningkatkan Hasil Belajar Pendidikan Agama Islam
}

\author{
Andi Milda Malia , Munir Yusuf , A. Sukmawati Assa'ad \\ Prodi Pendidikan Agama Islam, IAIN Palopo \\ Email: andimildamalia@gmail.com
}

\begin{abstract}
This study aims to to see the application of cooperative kind of classroom learning type student teams achievement division ( stad) in improving the learning outcomes for islamic education a student of class viiib 7 palopo public junior high schools. This research is research the act of class. The research results show that the results of a: (1) student learning on the subjects of islamic education class VIIIB in public junior high schools 7 palopo before cooperative kind of classroom learning type student teams achievement division ( stad) applied is currently far of the value of the criteria set minimum ketuntasan $\mathrm{kkm}, 78$. (2) the application of cooperative kind of classroom learning on the subjects of islamic education class viiib in public junior high schools 7 palopo it was rarely applied by reason of the condition of class that does not support. (3) the application of cooperative kind of classroom learning type student achievement division (stad teams to improve learning outcomes for islamic education a student of class VIIIB public junior high schools 7. It is seen of student test scores in the cycle iii with grade point average 89,6 .
\end{abstract}

Keywords: Learning Model, student teams achievement division, learning outcomes, islamic education

\begin{abstract}
Abstrak
Penelitian ini bertujuan untuk melihat penerapan model pembelajaran Cooperative Learning Tipe Student Teams Achievement Division (STAD) dalam meningkatkan hasil belajar pendidikan agama Islam Siswa Kelas VIIIB SMP Negeri 7 Palopo. Penelitian ini adalah penelitian tindakan kelas. Hasil penelitian menunjukkan bahwa : (1) gambaran hasil belajar siswa pada mata pelajaran pendidikan agama Islam kelas VIIIB di SMP Negeri 7 Palopo sebelum model pembelajaran Cooperative Learning tipe Student Teams Achievement Division (STAD) diterapkan masih sangat jauh dari nilai Kriteria Ketuntasan Minimal (KKM) yaitu 78. (2) Penerapan model pembelajaran Cooperative Learning pada mata pelajaran pendidikan agama Islam kelas VIIIB di SMP Negeri 7 Palopo masih jarang diterapkan dengan alasan kondisi kelas yang tidak mendukung. (3) Penerapan Model Pembelajaran Cooperative Learning Tipe Student Teams Achievement Division (STAD) dapat meningkatkan hasil belajar pendidikan agama Islam siswa kelas VIIIB SMP Negeri 7 Palopo,
\end{abstract}

Kata Kunci: Model Pembelajaran, STAD, Hasil Belajar, Pendidikan Agama Islam. 


\section{Pendahuluan}

Model pembelajaran merupakan pola kegiatan yang secara terstruktur membimbing dan mengarahkan jalannya proses pembelajaran, terciptanya pembelajaran yang menarik dalam kerangka membelajarkan siswa menuju pencapaian tujuan pembelajaran yang telah ditetapkan. Penggunaan model pembelajaran yang tepat bertujuan untuk menciptakan pembelajaran yang memungkinkan siswa dapat belajar secara aktif dan menyenangkan sehingga siswa dapat meraih hasil belajar dan prestasi yang optimal. Anurrahman dalam buku Syamsu Sanusi berpendapat penggunaan model pembelajaran yang tepat dapat mendorong tumbuhnya rasa senang peserta didik terhadap pelajaran, menumbuhkan dan meningkatkan motivasi dalam mengerjakan tugas, memberikan kemudahan bagi peserta didik untuk memahami pelajaran sehingga memungkinkan mereka mencapai hasil belajar yang baik. ${ }^{1}$ Model pembelajaran diperuntukan bagi semua mata pelajaran di lembaga pendidikan formal termasuk dalam mata pelajaran Pendidikan Agama Islam.

Mengamati fenomena belajar-mengajar Pendidikan Agama Islam di SMP Negeri 7 Palopo kelas VIIIB, tampak bahwa hasil belajar siswa sangat jauh dari nilai Keriteria Ketuntasan Minimal (KKM) yang telah ditetapkan yaitu 78. Hal ini terjadi karena guru tidak mengembangkan mindset yang sesuai dengan perkembangan sistem pendidikan.

Model pembalajaran Cooperative Learning adalah kegiatanpembelajaran dengan cara berkelompok untuk bekerja sama saling membantu mengonstruksi konsep dan menyelesaikanpersoalan. ${ }^{2}$ Dalam model pembelajaran kooperatif ini, guru lebih berperan sebagai fasilitator yang berfungsi sebagai jembatan penghubung kearah pemahaman yang lebih tinggi, dengan catatan siswa sendiri. Guru tidak hanya memberikan pengetahuan kepada siswa, tetapi juga harus membangun pengetahuan dalam pikirannya. Siswa mempunyai kesempatan untuk mendapatkan pengalaman langsung dalam menerapkan ide-ide mereka, ini merupakan kesempatan bagi siswa untuk menemukan dan menerapkan ide-ide mereka sendiri.

Cooperative Learning dapat meningkatkan pemahaman siswa tentang isi materi, memahami konsep-konsep, serta mendorong siswa aktif, partisipatif, dan konstruktif terlibat dalam pelajaran. Cooperative Learning mempunyai dampak positif yaitu meningkatkan prestasi belajar siswa,

\footnotetext{
${ }^{1}$ Syamsu S, Strategi Pembelajaran: Meningkatkan Kompetensi Guru, (Cet. I; Makassar: Aksara Timur, 2015), h. 73.

${ }^{2}$ Aris Shoimin, 68 Model Pembelajaran Inovatif dalam Kurikulum 2013 (Cet. II; Yogyakarta: Ar-Ruzz Media, 2016), h. 45.
} 
meningkatkan kemampuan berfikir kritis, dan meningkatkan motivasi belajar.

Agus Suprijono berpendapat dalam bukunya

Dalam Cooperative Learning siswa (1) berbagi ide tentang suatu topik; (2) menganalisis suatu argumen, mengkritisi, atau mengevaluasi kesimpilan; (3) menerapkan konsep; (4) mereview melalui tanya jawab satu sama lain. ${ }^{3}$

Berdasarkan pemaparan di atas, dapat disimpulkan bahwa pembelajaran Cooperative Learning adalah konsep yang lebih luas meliputi semua jenis kerja kelompok termasuk bentuk-bentuk yang lebih dipimpin dan diarahkan oleh guru, menetapkan tugas dan pertanyaan-pertanyaan serta menyediakan bahan-bahan dan informasi yang dirancang untuk membantu peserta didik menyelesaikan masalah yang dimaksud. Guru biasanya menetapkan bentuk ujian pada akhir tugas.

Students Teams Achievement Divisions (STAD) ini mula-mula dikembangkan oleh Robert Slavin dan kawan-kawannya dari Universitas John Hopkins. Siswa dalam suatu kelas tertentu dipecah menjadi kelompok dengan anggota empat sampai lima orang, setiap kelompok harus heterogen, terdiri dari laki-laki dan perempuan, berasal dari berbagai suku, memiliki kemampuan, tinggi, sedang dan rendah. Anggota tim menggunakan lembar kegiatan atau perangkat pembelajaran yang lain untuk menuntaskan materi pelajarannya dan kemudian membantu satu sama lain untuk memahami bahan pelajaran melalui tutorial, kuis, satu sama lain, dan atau melakukan diskusi. ${ }^{4}$

Pada saat menerapkan media pembelajaran harus memperhatikan partisipasi aktif di dalam proses pembelajaran. Siswa dirangsang menyelesaikan masalah-masalah baik secara individu maupun kelompok. Dan pada akhirnya diharapkan dapat terlatih untuk belajar mandiri dan tidak selalu bergantung kepada guru.

Sebagimana firman Allah Swt dalam QS.An-Nahl/16 : 125

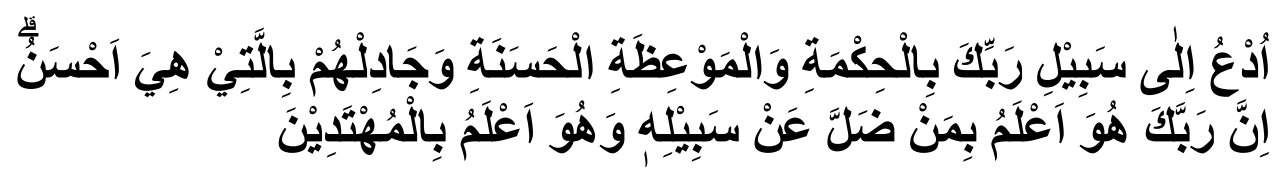

\footnotetext{
${ }^{3}$ Agus Suprijono, Cooperative Learning Teori dan Aplikasi PAIKEM, (Cet. XIV; Yogyakarta:Pustaka Pelajar, 2015), h. 59.

${ }^{4}$ Aris Shoimin, 68 Model Pembelajaran Inovatif dalam Kurikulum 2013 (Cet. II; Yogyakarta: Ar-Ruzz Media, 2016), h. 185 - 186.
} 
Terjemahannya:

"Serulah (manusia) kepada jalan TuhanMu dengan hikmah dan pelajaran yang baik. Sesuhngguhnya Tuhanmu Dialah yang lebih mengetahui tentang siapa yang tersesat dari jalan-Nya dan Dialah yang mengetahui orangorang yang mendapat pentunjuk." ${ }^{5}$

Ayat di atas menjelaskan bahwa sebagai manusia kita diperintahkan agar mengajak sesama untuk tetap berada di jalan Allah dengan cara yang baik. Artinya dengan adanya model pembelajaran Student Teams Achievement Division (STAD) yang di jalankan oleh guru kepada siswa merupakan salah satu jalan yang baik untuk merangsang daya tarik siswa untuk lebih serius dan semangat dalam mengikuti materi pada mata pelajaran Pendidikan Agama Islam yang diberikan oleh guru.

a. Langkah-langkah Pembelajaran Students Teams Achievement Divisions (STAD)

1) Guru menyampaikan materi pelajaran kepada siswa sesuai kompotensi dasar yang akan dicapai. Guru dapat menggunakan berbagai pilihan dalam berbagai materi pembelajaran, misal, dengan metode penemuan terbimbing atau metode ceramah. Langkah ini tidak harus dilakukan dalam satu kali pertemuan, tetapi dapat lebih dari satu.

2) Guru memberikan tes/kuis kepada setiap siswa secara individu sehingga diperoleh nilai awal kemampuan siswa.

3) Guru membentuk beberapa kelompok. Setiap kelompok terdiri dari 45 anggota, di mana anggota kelompok mempunyai kemampuan akademik yang berbeda-beda (tinggi, sedang, dan rendah). Jika mungkin, anggota kelompok berasal dari budaya atau suku yang berbeda serta memerhatikan kesetaraan gender.

4) Guru memberikan tugas kepada kelompok berkaitan dengan materi yang telah diberikan, mendiskusikannya secara bersama-sama, saling membantu antaranggota lain serta membahas jawaban tugas yang diberikan guru. Tujuan utamanya adalah memastikan bahwa setiap kelompok dapat menguasai konsep dan materi. Bahan tugas untuk kelompok dipersiapkan oleh guru agar kompotensi dasar yang diharapkan dapat dicapai.

5) Guru memberikan tes/kuis kepada setiap siswa secara individu.

6) Guru memfasilitasi siswa dalam membuat rangkuman, mengarahkan, dan memberikan penegasan pada materi pembelajaran yang telah dipelajari. 
7) Guru memberi penghargaan kepada kelompok berdasarkan perolehan nilai peningkatan hasil belajar individual dari nilai awal ke nilai kuis berikutnya. ${ }^{6}$

b. Kelebihan dan Kekurangan Model Pembelajaran Students Teams Achievement Divisions (STAD)

1. Kelebihan

a) Siswa bekerja sama dalam mencapai tujuan dengan menjungjung tinggi norma-norma kelompok.

b) Siswa aktif membantu dan memotivasi semangat untuk berhasi bersama.

c) Aktif berperan sebagai tutor sebaya untuk lebih meningkatkan keberhasilan kelompok.

d) Interaksi antarsiswa seiring dengan peningkatan kemampuan mereka dalam berpendapat.

e) Meningkatkan kecakapan individu.

f) Meningkatkan kecakapan kelompok.

g) Tidak bersifat kompetitif.

h) Tidak memiliki rasa dendam.

2. Kekurangan

a) Kontribusi dari siswa berprestasi rendah menjadi kurang.

b) Siswa berprestasi tinggi akan mengarah pada kekecewaan karena para anggota yang pandai lebih dominan.

c) Membutuhkan waktu yang lebih lama untuk siswa sehingga sulit mencapai target kurikulum.

d) Membutuhkan waktu yang lebih lama sehingga pada umumnya guru tidak mau menggunakan pelajaran kooperatif. ${ }^{7}$

2. Hasil Belajar

Merujuk pemikiran Gagne yang dikutip oleh Agus Suprijono, hasil belajar berupa: 8

a) Informasi verbal yaitu kapabilitas mengungkapkan pengetahuan dalam bentuk bahasa, baik lisan maupun tertulis. Kemampuan merespon secara spesifik terhadap rangsangan spesifik. Kemampuan tersebut tidak memerlukan manipulasi simbol, pemecahan masalah, maupun penerapan aturan.

b) Keterampilan intelektual yaitu kemampuan mempersentasikan konsep dan lambang. Keterampilan intelektul terdiri dari kemampuan

\footnotetext{
${ }^{6}$ Aris Shoimin, 68 Model Pembelajaran Inovatif dalam Kurikulum 2013 , (Cet. II; Yogyakarta: Ar-Ruzz Media, 2016), h. 187-188.

${ }^{7}$ Aris Shoimin, 68 Model Pembelajaran Inovatif dalam Kurikulum 2013, (Cet. II; Yogyakarta: Ar-Ruzz Media, 2016) h. 189.

${ }^{8}$ Agus Suprijono, Cooperative Learning Teori dan Aplikasi PAIKEM, (Cet. XIV; Yogyakarta: Pustaka Pelajar, 2015), h.5-6.
} 
mengategorisasi, kemampuan analisis-sintesis fakta-konsep dan mengembangkan prinsip-prinsip keilmuan. Keterampilan intelektual merupakan kemampuan melakukan aktivitas kognitif bersifat khas.

c) Strategi kognitif yaitu kecakapan menyalurkan dan mengarahkan aktivitas kognitifnya sendiri. Kemampuan ini meliputi kemampuan konsep dan kaidah dalam memecahkan masalah.

d) Keterampilan motorik yaitu kemampuan melakukan serangkaian gerak jasmani dalam urusan dan koordinasi, sehingga terwujud otonamisme gerak jasmani.

e) Sikap adalah kemampuan menerima atau menolak objek berdasarkan penilain terhadap objek tersebut. Sikap berupa kemampuan menginternalisasi dan eksternalisasi nilai-nilai. Sikap merupakan kemampuan menjadikan nilai-nilai sebagai standar perilaku.

Selain Gagne, dalam bukunya Agus Suprijono, Bloom berpendapat bahwa hasil belajar mencakup kemampuan kognitif, afektif, dan psikomotorik. Domain kognitif adalah knowledge (pengetahuan, ingatan), comprehension (pemahaman, menjelaskan, meringkas, contoh), application (menerapkan), analysis (menguraikan, menentukan hubungan), syntesis (mengorganisasikan, merencanakan, membentuk banguna baru), dan evaluin (menilai). Domain afektif adalah receiving (sikap menerima), responding (memberikan respon), valuing (nilai), organization (organisasi), caracterization (karakterisasi). Domain psikomotorik meliputi initiatory, pre-routine, dan rountinized. Psikomotor juga mencakup keterampilan produktif, teknik, fisik, sosial, manajerial, dan intelektual. ${ }^{9}$

Berdasarkan pendapat di atas, dapat disimpulkan bahwa setiap kegiatan yang dilakukan siswa akan menghasilkan perubahan-perubahan dalam dirinya meliputi perubahan kognitif, afektif, dan psikomotorik. Hasil belajar adalah pola-pola perbuatan, nilai-nilai, pengertian-pengertian, sikap-sikap, apresiasi dan keterampilan berupa perubahan-perubahan yang bersifat maju dan positif.

Atas dasar masalah di atas, peneliti mencoba menggunakan model pembelajaran Cooperative Learning tipe Student Teams Achievement Division (STAD) kelas VIII ${ }_{\mathrm{B}}$ SMP Negeri 7 Palopo, dengan harapan siswa dapat tertarik dan akhirnya hasil belajar Pendidikan Agama Islam mereka dapat meningkat.

\footnotetext{
${ }^{9}$ Agus Suprijono, Cooperative Learning Teori dan Aplikasi PAIKEM, (Cet. XIV; Yogyakarta:Pustaka Pelajar, 2015), h. 6-7.
} 


\section{Metode Penelitian}

Penelitian ini merupakan penelitian tindakan kelas (Classroom Action Research) yang bermaksud menggambarkan tentang penerapan model pembelajaran Cooperative Learning tipe Student Teams Achievement Division (STAD) dalam meningkatkan hasil belajar mata pelajaran pendidikan agama Islam siswa kelas VIIIB SMP Negeri 7 Palopo. Peneliti menggunakan model penelitian tindakan kelas yang diterapkan oleh Kurt Lewin. Kurt Lewin menjelaskan bahwa ada 4 hal yang harus dilakukan dalam proses penelitian tindakan yakni perencanaan, tindakan, observasi, dan refleksi. Pelaksanaan penelitian tindakan adalah proses yang terjadi dalam suatu lingkaran yang terus-menerus. ${ }^{10}$

Dalam mengumpulkan data di lapangan, penulis menggunakan beberapa teknik Field Research (peneliti lapangan). Adapun dalam penelitian ini, peneliti akan menggunakan Interview (wawancara), Dokumentasi, Observasi (pengamatan), serta tes. Teknik analisi data yang digunakan, antara lain:

1. Untuk menganalisis data hasil tes peserta didik, untuk mengetahui tingkat hasil belajarnya di gunakan rumus sebagai berikut:

1) Rumus Mencari Rata-rata

$$
M_{X=\frac{\sum X}{N}}
$$

$$
\begin{aligned}
& \text { Keterangan: } \quad \mathrm{M}_{\mathrm{X}}=\text { Mean yang dicari } \\
& \sum x=\text { Jumlah dari skor yang ada } \\
& \mathrm{N} \text { = Banyaknya skor-skor itu sendiri.11 }
\end{aligned}
$$

2) Rumus Mencari Persentase

$$
\mathrm{P}=\frac{\mathrm{F}}{\mathrm{N}} \times 100 \%
$$

Keterangan: $\quad \mathrm{F}=$ Frekuensi yang sedang dicari persentasenya. $\mathrm{N}=$ Jumlah frekuensi/banyaknya individu.

$$
\mathrm{P}=\text { Angka persentase. }{ }^{12}
$$

2. Untuk menganalisis teknik pengumpulan data dengan wawancara, dokumentasi, observasi, dilakukan analisis dengan menggunakan teknik deskriptif, yaitu uraian yang bersifat pemaparan dengan menjelaskan data yang ditemukan secara obyektif tanpa disertai pendapat dari peneliti.

${ }^{10}$ Wina Sanjaya, Penelitian Tindakan Kelas, (Cet.V; Jakarta: Kencana Prenata Media Group, 2013), h. 49.

${ }^{11}$ Anas Sudijono, Pengantar Statistik Pendidikan, (Cet. XXII; Jakarta: Rajawali Pers, 2010), h. 81.

${ }^{12}$ Anas Sudijono, Pengantar Statistik Pendidikan, (Cet. XXII; Jakarta: Rajawali Pers, 2010), h. 43. 
Indikator keberhasilan atau kriteria ketuntasan minimal (KKM) yang telah ditetapkan di SMP Negeri 7 Palopo khususnya mata pelajaran Pendidikan Agama Islam kelas XIIIB adalah 78 (nilai). Apabila skor rata-rata yang diperoleh siswa telah mencapai nilai 78 maka siswa dikatakan telah lulus atau berhasil mengikuti pembelajaran Pendidikan Agama Islam.

\section{Pelaksanaan PTK Siklus I}

1) Perencanaan

a) Membuat Rencana Pelaksanaan Pembelajaran (RPP) dengan materi yang telah ditetapkan sesuai dengan model pembelajaran Student Teams Achievement Division (STAD). Pada siklus I materi yang disampaikan meliputi Standar Kompotensi (SK) yaitu Menghindari Perilaku Tercela, yang terdiri dari 2 Kompotensi Dasar (KD). 1.1. Menjelaskan pengertian ananiah, ghadab, hasad, ghibah dan namimah. 1.2. Menyebutkan dalil tentang ananiah, ghadab, hasad, ghibah dan namimah.

Catatan: Setiap Kompotensi Dasar dilaksanakan dengan satu kali pertemuan. Kompotensi Dasar (KD) 1.1. satu kali pertemuan dengan alokasi waktu 2 x 40 menit dan Kompotensi Dasar (KD) 1.2. satu kali pertemuan dengan alokasi waktu 1 x 40 menit.

b) Menyiapkan sumber belajar

c) Membuat konsep pembagian kelompok heterogen perbedaan tingkat kecerdasan pertemuan pertama dibagi sesuai tinggi bada yang berbeda, pertemuan kedua tahun lahir ganjil dan genap.

d) Menyiapkan instrumen yang terdiri dari:

(1) Lembar Observasi Aktivitas belajar siswa

Lembar observasi berisi indikator-indikator aktivitas belajar siswa yang digunakan sebagai pegangan bagi peneliti dalam melakukan observasi terhadap siswa dalam pembelajaran pendidikan agama Islam dengan model Student Teams Achievement Division (STAD).

(2) Lembar observasi kegiatan guru

Lembar observasi guru berisi indikator-indikator keterlaksanaan langkah-langkah kegiatan pembelajaran dengan menggunakan model STAD pada pembelajaran pendidikan agama Islam pada kelas VIII ${ }_{\text {B }}$ SMP Negeri 7 Palopo.

(3) Soal tes evaluasi

Tes diberikan pada siswa untuk mengukur seberapa besar pemahaman siswa terhadap materi yang diajarkan. Tes berupa tes objektif (pilihan ganda) terdiri dari 10 butir item soal yang dikerjakan secara individu. Soal tes diambil dari materi Kompetesi Dasar (KD) 1.1 dan 1.2.

e) Melakukan koordinasi dengan guru sebagai kolabolator dan teman sejawat yaitu mahasiswa. 
f) Memberikan pengarahan kepada teman sejawat yang bertindak sebagai observer.

2) Pelaksanaan

Pelaksanaan merupakan tindakan atau implementasi dari semua rencana yang telah dibuat. Kegiatan yang dilakukan peneliti pada tahap ini sesuai dengan Rencana Pelaksanaan Pembelajaran (RPP) yang telah peniliti buat setiap pertemuan.

3) Pengamatan

Pengamatan atau observasi dilakukan pada saat proses kegiatan pembelajaran berlangsung dengan menggunakan lembar observasi. Pada tahap ini siswa dan guru yang diamati untuk mengetahui aktivitas-aktivitas yang terjadi selama pembelajaran.

4) Refleksi

Adapun kegagalan yang terjadi pada siklus I yaitu :

a) Guru tidak mengucapkan salam pada awal pertemuan

b) Guru tidak menyakan keadaan siswa

c) Sebagian siswa belum terbiasa belajar dengan menggunakan model pembelajaran Student Teams Achievemen Division (STAD), sehingga masih banyak yang kaku dengan teman kelompok yang telah dibagikan secara heterogen dengan tingkat kecerdasan siswa yang berbeda (pertemuan kesatu siswa dibagi dengan tinggi badan yang berbeda dan pertemuan kedua siswa dibagi sesuai tahun lahir angka tunggal dan ganjil) .

d) Sesuai dengan lembar observasi aktivitas pembelajaran siswa pada pertemuan pertama dan kedua, masih ada yang belum terlalu aktif dalam kelompok dengan nilai rata-rata 4,5. Nilai rata-rata siswa yang fokus terhadap materi hanya 16. siswa yang menguasai materi akhlak menghindari perilaku tercela ananiah, ghadab, hasad, ghibah dan amimah dengan nilai rata-rata 14 , dan siswa yang mengajukan pertanyaan dengan nilai rata-rata 4,5 .

e) Nilai hasil belajar siswa belum mencapai nilai kriteria ketuntasan minimal dengan nilai rata-rata 60 .

Diagram 1. Perolehan hasil belajran siklus I

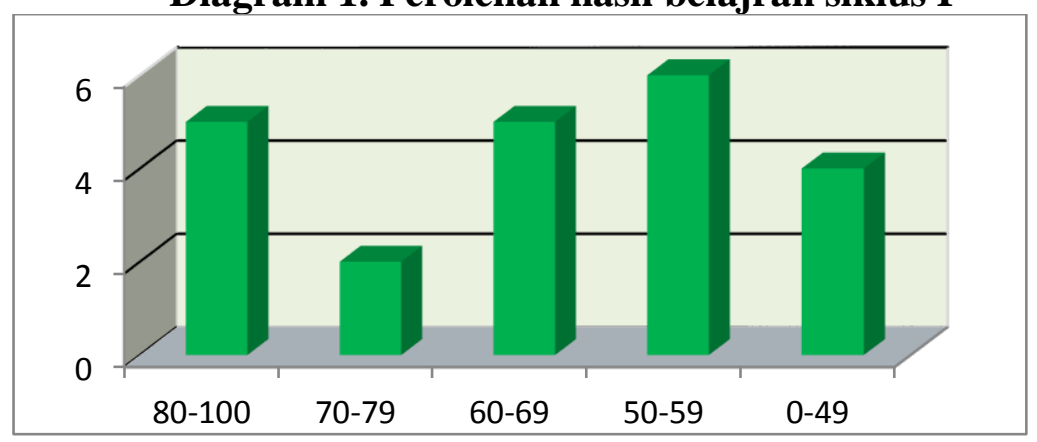


Untuk memperbaiki kelemahan dan mempertahankan keberhasilan yang telah dicapai pada siklus I, maka pada pelaksanaan siklus II dibuat perencanaan baru.

(1) Guru (peneliti) memancing siswa dengan memberikan pertanyaan agar siswa lebih memperhatikan dan lebih aktif mengikuti pelajaran pendidikan agama Islam.

(2) Guru (peneliti) membimbing siswa yang telah berhasil aktif terhadap kelompok yang mereka miliki untuk mendiskusikannya sesuai dengan soal dan jawaban yang mereka dapatkan, lalu guru menunjuk perwakilan dari setiap kelompok untuk menulis dan membacakan hasil diskusi mereka.

(3) Guru (peneliti) memantau setiap kelompok agar semua anggota kelompok dapat berpartisipasi dalam kegiatan diskusi.

(4) Guru memberikan tes/kuis kepada siswa secara individu terkait materi yang dibahas.

(5) Guru memotivasi agar siswa semangat dalam bekerja.

\section{Pelaksanaan PTK Siklus II}

1) Perencanaan

a) Membuat Rencana Pelaksanaan Pembelajaran (RPP) dengan materi yang telah ditetapkan sesuai dengan model pembelajaran Student Teams Achievement Division (STAD). Pada siklus ke- II materi yang disampaikan meliputi Standar Kompotensi (SK) yaitu Menghindari Perilaku Tercela ananiah, ghadab, hasad, ghibah dan namimah, yang terdiri dari 2 Kompotensi Dasar (KD). 4.3. Menyebutkan contoh-contoh ananiah, ghadab, hasad, ghibah dan namimah. 4.4. Menghindari perilaku tercela ananiah, ghadab, hasad, ghibah dan namimah dalam kehidupan sehari-hari.

Catatan: Setiap Kompotensi Dasar dilaksanakan dengan satu kali pertemuan. Kompotensi Dasar (KD) 1.3. satu kali pertemuan dengan alokasi waktu 2 x 40 menit dan Kompotensi Dasar (KD) 1.4. satu kali pertemuan dengan alokasi waktu 1 x 40 menit.

b) Menyiapkan sumber belajar

c) Membuat konsep pembagian kelompok heteregon dengan tingkat kecerdasan yang berbeda. Pertemuan pertama siswa dibagi berdasarkan tanggal lagir ganjil genap, pertemuan kedua siswa dibagi dengan suku yang berbeda.

d) Menyiapkan instrumen yang terdiri dari:

(1) Lembar Observasi Aktivitas belajar siswa

Lembar observasi berisi indikator-indikator aktivitas belajar siswa yang digunakan sebagai pegangan bagi peneliti dalam melakukan observasi terhadap siswa dalam pembelajaran pendidikan agama Islam dengan model Student Teams Achievement Division (STAD). 
(2) Lembar observasi kegiatan guru

Lembar observasi guru berisi indikator-indikator keterlaksanaan langkah-langkah kegiatan pembelajaran dengan menggunakan model Student Teams Achievement Division (STAD) pada pembelajaran pendidikan agama Islam kelas VIIIB SMP Negeri 7 Palopo.

(3) Soal tes evaluasi

Tes diberikan pada siswa untuk mengukur seberapa besar pemahaman siswa terhadap materi yang diajarkan. Tes berupa tes objektif (pilihan ganda) terdiri dari 10 butir item soal yang dikerjakan secara individu. Adapun soalsoal tes tersebut daimbil dari materi Kompotensi Dasar (KD) 1.3 dan 1.4.

e) Melakukan koordinasi dengan guru sebagai kolabolator dan teman sejawat yaitu mahasiswa.

f) Memberikan pengarahan kepada teman sejawat yang bertindak sebagai observer.

2) Pelaksanaan

Pada tahap ini, pelaksanaan siklus kedua sama dengan pelaksanaan siklus pertama dengan melihat Rencana Pelaksanaan Pembelajaran (RPP) yang telah peneliti buat setiap pertemuannya sesuai dengan hasil dari refleksi dari siklus I.

3) Pengamatan

Pada tahap ini, peneliti melakukan pengamatan dan mencatat semua hal yang diperlukan dan terjadi selama pelaksanaan tindakan berlangsung selama proses pembelajaran. Hal ini dapat dilihat juga dari lembar observasi siswa. Berdasarkan pengamatan yang dilakukan dengan penerapan model pembelajaran Student Teams Achievement Division (STAD) diperoleh hasil sebagai berikut:

a) Pertemuan pertama dan kedua siswa sudah terbiasa menggunakan model pembelajaran Student Teams Achievement Division (STAD) hal ini dilihat dari lembar observasi siswa bahwa dari jumlah keseluruhan siswa yang hadir sudah fokus terhadap materi. hampir semua siswa sudah aktif dalam kelompok mereka. Adapun siswa yang tidak aktif dengan nilai rata-rata 2,5 dan menguasai materi dengan nilai rata-rata 20,5, siswa yang bertanya dengan nilai rata-rata 6.

b) Ketika dilakukan tes evaluasi pada siklus kedua siswa mendapat nilai ratarata 84,1. Hal ini mununjukkan bahwa hasil belajar pendidikan agama Islam siswa meningkat. 


\section{Diagram 2. Perolehan hasil belajran siklus II}

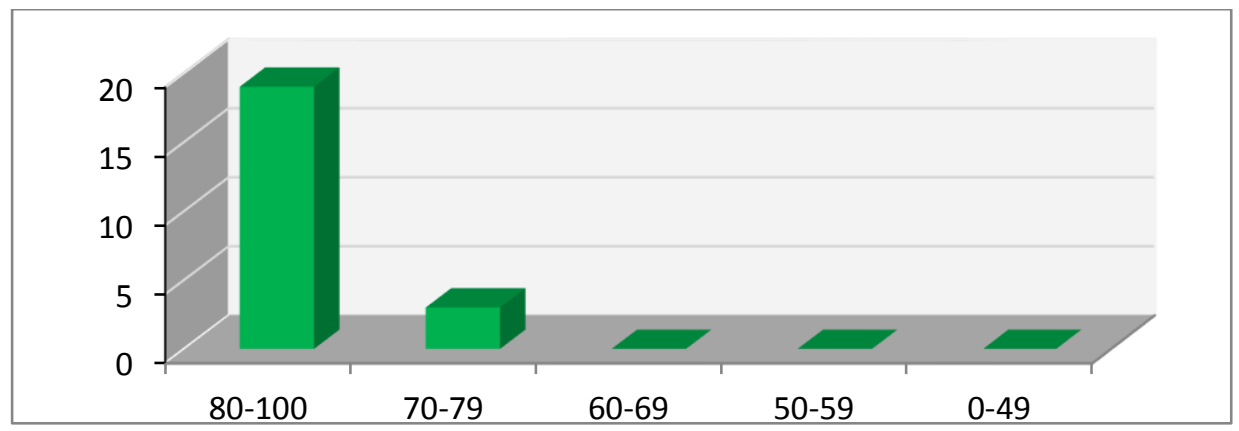

4) Refleksi

Refleksi dilakukan untuk menentukan apakah siklus kedua harus diulangi atau sudah berhasil. Berdasarkan hasil tes evaluasi prasiklus dan siklus pertama serta hasil lembar observasi siswa dalam proses pembelajaran pendidikan agama Islam dengan menerapkan model pembelajaran Student Teams Achievement Division (STAD) telah berhasil meningkatkan hasil belajar siswa. Hal ini dilihat dari hasil tes evaluasi siswa pada siklus kedua mencapai nilai rata-rata 84,1 lebih meningkat dibanding pada siklus pertama yang hanya mencapai nilai rata-rata 60 Selain itu, Hasil lembar observasi aktivitas siswa saat proses pembelajaran berlangsung juga meningkat. Hal ini dilihat dari hampir keseluruhan siswa kelas VIII B yang berhasil aktif dalam kelompok diskusi.

Meskipun hasil belajar siswa pada mata pelajaran pendidikan agama Islam sudah meningkat dan melebihi nilai Kriteria Ketuntasan Minimal (KKM), untuk lebih membuktikan apakah model Student Teams Achievement Division (STAD) benar dapat meningkatkan hasil belajar siswa VIII в pada mata pelajaran pendidikan agama Islam peneliti perlu melanjutkan pada siklus ketiga.

Untuk memperbaiki kelemahan dan mempertahankan keberhasilan yang telah dicapai pada siklus II , maka pada pelaksanaan siklus III dibuat perencanaan baru.

(1) Guru (peneliti) memberi game berupa senam otak pada siswa guna melatih konsentrasi siswa.

(2) Guru (peneliti) memancing siswa dengan memberi kuis uji keberanian siswa siapa cepat ajukan tangan maka akan menjawab pertanyaan kemudian menununjuk salah satu siswa lainnya untuk diberi pernyaan oleh guru (penenliti). Hal ini dilakukan agar siswa lebih memperhatikan dan lebih antusias aktif mengikuti pelajaran pendidikan agama Islam.

(3) Guru (peneliti) membimbing siswa yang telah berhasil aktif terhadap kelompok yang mereka miliki untuk mendiskusikannya sesuai dengan soal 
dan jawaban yang mereka dapatkan, lalu guru menunjuk perwakilan dari setiap kelompok untuk menulis dan membacakan hasil diskusi mereka.

(4) Guru (peneliti) memantau setiap kelompok agar semua anggota kelompok dapat berpartisipasi dalam kegiatan diskusi.

(5) Guru memotivasi agar siswa semangat dalam bekerja.

(6) Guru memberikan tes/kuis kepada siswa secara individu terkait materi yang dibahas untuk mengetahui seberapa jauh siswa menguasai materi yang telah mereka diskusikan dengan teman kelompok mereka.

(7) Guru (peneliti) memberi penghargaan kepada siswa yang berhasil menjawab pertanyaan dan memberi penguatan kepada siswa yang belum berhasil menguasai materi.

\section{Pelaksanaan PTK Siklus III}

\section{1) Perencanaan}

a) Membuat Rencana Pelaksanaan Pembelajaran (RPP) dengan materi yang telah ditetapkan sesuai model pembelajaran Student Teams Achievement Division (STAD). Pada siklus III materi yang disampaikan meliputi Standar Kompotensi (SK) yaitu membiasakan perilaku terpuji yang terdiri dari 3 Kompotensi Dasar (KD). 1.1. Menjelaskan pengertian zuhud dan tawakkal. 1.2. menyebutkan contoh perilaku zuhud dan tawakal. 1.3. Membiasakan perilaku zuhud dan tawakkal dalam kehidupan sehari-hari.

Catatan: Kompotensi Dasar (KD) 1.1. dan Kompetensi dasar (KD) 1.2. satu kali pertemuan dengan alokasi waktu 1 x 40 menit. Kompotensi Dasar (KD) 1.3. satu kali pertemuan dengan alokasi waktu 2 x 40 menit.

a) Menyiapkan instrumen yang terdiri dari:

(1) Lembar Observasi Aktivitas belajar siswa

Lembar observasi berisi indikator-indikator aktivitas belajar siswa yang digunakan sebagai pegangan bagi peneliti dalam melakukan observasi terhadap siswa dalam pembelajaran pendidikan agama Islam dengan model Student Teams Achievement Division (STAD).

(2) Lembar observasi kegiatan guru

Lembar observasi guru berisi indikator-indikator keterlaksanaan langkah-langkah kegiatan pembelajaran dengan menggunakan model Student Teams Achievement Division (STAD) pada pembelajaran pendidikan agama Islam kelas VIII ${ }_{\mathrm{B}}$ SMP Negeri 7 Palopo.

(3) Soal tes evaluasi

Tes diberikan pada siswa untuk mengukur seberapa besar pemahaman siswa terhadap materi yang diajarkan. Tes berupa tes objektif (pilihan ganda) terdiri dari 10 butir item soal yang dikerjakan secara individu terkait materi siklus III. 
b) Melakukan koordinasi dengan guru sebagai kolabolator dan teman sejawat yaitu mahasiswa.

c) Memberikan pengarahan kepada teman sejawat yang bertindak sebagai observer.

2) Pelaksanaan

Pada tahap ini, pelaksanaan siklus III sama dengan pelaksanaan siklus I dan II dengan melihat Rencana Pelaksanaan Pembelajaran (RPP) yang telah peneliti buat setiap pertemuannya sesuai dengan hasil dari refleksi siklus II.

Catatan: pembagian kelompok secara heterogen sesuai tingkat kecerdasan pertemuan pertama dibagi dengan sistem berhitung kesamping, pertemuan kedua sistem berhitung ke belakang.

3) Pengamatan

Pada tahap ini, peneliti melakukan pengamatan dan mencatat semua hal yang diperlukan dan terjadi selama pelaksanaan tindakan berlangsung selama proses pembelajaran. Hal ini dapat dilihat juga dari lembar observasi siswa. Berdasarkan pengamatan yang dilakukan dengan penerapan model pembelajaran Student Teams Achievement Division (STAD) diperoleh hasil sebagai berikut:

a) Pertemuan pertama dan kedua siswa lebih antusias belajar dengan menggunakan model pembelajaran Student Teams Achievement Division (STAD) hal ini dilihat dari lembar observasi siswa bahwa dari jumlah keseluruhan siswa yang hadir sudah fokus terhadap materi. hampir semua siswa sudah aktif dalam kelompok mereka. Adapun siswa yang tidak aktif dengan nilai rata-rata 2 , menguasai materi dengan nilai rata-rata 21 , siswa yang bertanya dengan nilai rata-rata 10 .

b) Ketika dilakukan tes evaluasi pada siklus ketiga siswa mendapat nilai ratarata 89,6 . Hal ini mununjukkan bahwa hasil belajar pendidikan agama Islam siswa meningkat.

Diagram 3. Perolehan hasil belajran siklus III

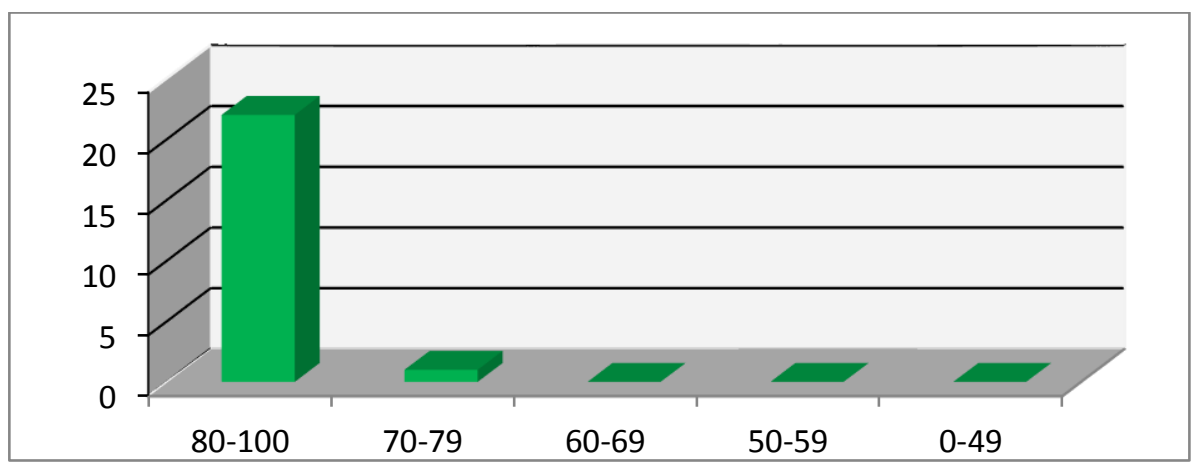


4) Refleksi

Berdasarkan hasil tes evaluasi prasiklus, siklus I dan siklus II serta hasil lembar observasi siswa dalam proses pembelajaran pendidikan agama Islam dengan menerapkan model Student Teams Achievement Division (STAD) telah berhasil meningkatkan hasil belajar siswa. Hal ini dilihat dari hasil tes evaluasi siswa pada siklus ketiga mencapai nilai rata-rata 89,6 lebih meningkat dibanding pada siklus pertama dan kedua. Selain itu, hasil lembar observasi aktivitas siswa saat proses pembelajaran berlangsung juga meningkat. Hal ini dilihat dari hampir keseluruhan siswa kelas VIIIB yang berhasil aktif dalam kelompok diskusi dan sangat antusias menerima materi melalui model Cooperative Learning tipe Student Teams Achievement Division (STAD). Dengan adanya peningkatan tersebut membuktikan bahwa model Cooperative Learning tipe Student Teams Achievement Division (STAD) dapat meningkatkan hasil belajar siswa, olehnya itu penelitian berhenti pada siklus III.

\section{Penutup}

Penerapan model pembelajaran Cooperative Learning Tipe Student Teams Achievement Division (STAD) dapat meningkatkan hasil belajar Pendidikan Agama Islam siswa VIIIB di SMP Negeri 7 Palopo, melihat perbandingan sebelum diterapkannya model pembelajaran tersebut (prasiklus), Siklus I, siklus II dan siklus III. Data yang diperoleh menunjukkan bahwa nilai rata-rata siswa VIIIB sebelum diterapkan model pembelajaran Cooperative Learning Tipe Student Teams Achievement Division (STAD) 32. Pada siklus I peneliti telah menerapkan model pembelajaran Cooperative Learning Tipe Student Teams Achievement Division (STAD) dan nilai hasil penelitian belum maksimal dengan nilai rata-rata 60 sehingga peneliti merencanakan perbaikan yang akan diterapkan pada siklus II. Maka hasil tes siklus II rata-rata 84,1. Untuk mengetahui apakah model pembelajaran Cooperative Learning tipe Student Teams Achievement Division (STAD) benar dapat meningkatkan hasil belajar siswa VIII ${ }_{B}$ SMP Negeri 7 Palopo pada mata pelajaran pendidikan agama Islam, peneliti melanjutkan ke siklus III. Adapun hasil tes siklus III dengan nilai rata-rata 89,6. Selain itu, Observasi dilakukan pada siswa selama mengikuti proses pembelajaran pendidikan agama Islam dengan menggunakan model pembelajaran Cooperative Learning Tipe Student Teams Achievement Division (STAD). Observasi pada siklus I, siklus II hingga ke siklus III mengalami peningkatan. 


\section{Daftar Pustaka}

al-Qur'anul Karim. 2013. Surabaya: UD Halim.

al-Bukhari al Ja'fi, Abu Abdullah Muhammad bin Ismail bin Ibrahim. 1981 M. Kitab Jenazah. Jus 2; Bairut-Libanon: Darul Fikri.

Arikunto, Suharsimi dkk. 2012. Penelitian Tindakan Kelas. Cet. XI; Jakarta: PT Bumi Aksara.

Azzubaidi, Zaenuddin Ahmad. 1986. Hadists Shahih Bukhari, trj. Muhammad Zuhri. jld. 1; Semarang: Toha Putra.

Fausan Hasan, Rizki, “Penerapan Model Pembelajaran Kooperatif Tipe Student Teams Achievement division (STAD) dalam Meningkatkan Hasil Belajar Akidah Akhlak (Penelitian Tindakan Kelas di MA Nihayatul Amal Karawang)", (Skripsi UIN Syarif Hidatullah Jakarta, 2014). [pdf], http://www.google.co.id/search?q=penerapan+model+pembelajara $\mathrm{n}+\mathrm{STAD}+$ dalam+meningkatkan+hasil+belajar+PAI+di+SMP\&client=u cweb-b\&channel=sb. (diakses pada tanggal 23 Agustus 2017)

Kementerian Agama RI. 2013. Al-Qur'an dan Terjemahnya. Surabaya: Fajar Mulya.

Maidah, Siti. 2015. Penerapan Model Aktive Learning dalam Meningkatkan Hasil Belajar Pendidikan Agama Islam pada Siswa Kelas IX-A SMP Negeri 1 Mangkutana. Skripsi IAIN Palopo.

Marwiyah, 2015. Perencanaan Pembelajarran Pendidikan Agama Islam. Cet. I; Makassar: Aksara Timur.

Muslihah, Eneng. 2011. Ilmu Pendidikan Islam. Cet.I, Jakarta: Diadit Media.

S, Syamsu. 2015. Strategi Pembelajaran Meningkatkan Kompotensi Guru. Cet. I; Makassar: Aksara Timur.

Sanjaya, Wina. 2013. Penelitian Tindakan Kelas. Cet.V; Jakarta: Kencana Prenata Media Group.

Shoimin, Aris. 2016. 68 Model Pembelajaran Inovatif dalam Kurikulum 2013. Cet. II; Yogyakarta: Ar-Ruzz Media. 
Sudijono, Anas. 2010. Pengantar Statistik Pendidikan. Cet. XXII; Jakarta: Rajawali Pers.

Sugiyono. 2014. Metode Penelitian Kuantitatif Kualitatif dan R\&D. Cet, XX; Bandung: Alfabeta.

----------. 2013. Metode penelitian Kuantitatif, Kualitatif, dan Kombinasi (Mixed Methods). Cet. IV; Bandung: Alfabeta.

Sukring. 2013. Pendidik dan Peserta Didik dalam Pendidikan Islam. Cet. I; Yogyakarta: Graha Ilmu.

Suprijono, Agus. 2015. Cooperative Learning Teori dan Aplikasi PAIKEM. Cet. . XIV; Yogyakarta:Pustaka Belajar.

Suria. 2014. Penerapan Pembelajaran Index Card dalam Meningkatkan Hasil Belajar Siswa Pada Mata Pelajaran PAI di Sekolah Dasar Negeri 41 Boneposi Kecamatan Latimojong Kabupaten Luwu. Skripsi STAIN Palopo.

Syah, Muhibbin. 2009. Psikologi Belajar. Revisi 9; Jakarta: Rajawali Pers. 
116 |Andi Milda Malia, dkk/IQRO: Journal of Islamic Education Vol. 2, No.1, Juli 2019. 99-116

Halaman ini Sengaja dikosongkan 